\title{
油やしの生産について西アフリカと 東南アジアの比較研究
}

西川五 郎

緒言

油やしは油料作物のうちで単位面積当り油の収量がもっとも多いものでニ コやしについで重要な作物である.この二つの作物の生産地域は必ずしも同 一でない、ココやしの生産は東南アジアが中心になっているのに対して, 油 やしはアフリカ特に西アフリカが中心になっている. .しかし油やしの栽培適 地は東南アジアにもあり，スマトラ，マラヤなどにはかなりの栽培がある.

東南アジアの油やし生産はその歷史が比較的新しい.インドネシアでは1859 年に試作され本格的には1911年から，マラヤでは1917年から栽培が始められ た. もとより東南アジアには油やし栽培は存在しなかったので, 西アフリカ に由来するものが導入されて発展したものであるが，その発展過程に扔いて は西アフリカと東南アジアでは種々異なった点があり，そのことが今日両地 域に生産されるパーム油拈よびパーム核油の品質に対してもまた産品の流通 過程に対してもかなり暴なった影響を及ぼしているように考えられる。そこ でこれら雨地域に拈ける油やし生産の発展過程を農業生産の技術的立場から 比较硎究して，雨地域の油やしの今日の問題との関連を明らかにし，かつ今 後の改良点とそこにとられるべき技術の若干を指摘しょうとした，本研究結 果を要約すれば次の通りである.

\section{研究結果の要約}

1. 西アフリカに执ける油やし果契の採取が原住民による野生のものから の採取に始ったのに刘して, 東南アジアの油やしは当初から近代的農園農業 の産物として出発した。 
2. その結果西アフリカにおいては野生のものの採取から脱却して農羍に 油やしを導入するようになってからも生産の主体は住民農業の範瞦で取扱わ れてきた。いま，ナイジェリアにおける油やし生産の規模とパーム油生産高 の関係をみると，第 1 表のようであり，この間の事情を知ることができる.

第 1 表 ナイジェリアに挔ける油やしの生産規模とパーム油生産高

(単位 : $1,000 t$ )

\begin{tabular}{l|r|r|r|r|r|r|r}
\hline 区 分 & 1956 & 1957 & 1958 & 1959 & 1960 & 1961 & 1962 \\
\hline 小規模生産者 & 179 & 166 & 177 & 183 & 182 & 164 & 122 \\
プランテーション & 6 & 5 & 7 & 7 & 7 & 9 & 8 \\
\hline
\end{tabular}

(資料) Commonwealth Economic Committee, Vegetable Oil and Oil Seed 1964, より引用.

3. したがって西アフリカの油やしの多くは東南アジアにおける油やしの よらに生産物が近代的農園農業の高度の技術下に叔いて生産されたものでは なくて，低い栽培管理下に生産されてきた.

4. ことに東南アジアの油やしでは優良系統のもののみが選択溨培された のに対して，西アフリカでは種々雑多の系統のものが何らの選択も加党られ ることなく混然たる状態で生産されてきた。この事実は第 2 表に示すマラヤ 産とナイジェリア産の果実の組成の比较から知ることができる.

第 2 表 油やし果実の組成につき西アフリカ産と東南アジア産の比校

\begin{tabular}{|c|c|c|}
\hline 組 成 地 & マラヤ歴 & ナイジェリア应 \\
\hline パ - ム 油 & $29.0 \%$ & $22.0 \%$ \\
\hline 水分および乾燥残熦 & 35.0 & 21.0 \\
\hline 核 & 6.0 & 13.0 \\
\hline 款 & 30.0 & 44.0 \\
\hline 計 & 100.0 & 100.0 \\
\hline
\end{tabular}

（資料） Bunting, Georg and Milsum, The oil palm in Malaya, り引月.

5. この結果生産される油やし果実は優劣混在し,さわぬて不揃いのもの を生産することとなり，その後の調製処理，搾油などの能率を悪くし，また 製造された油，核の質も低くならざるを得なかった。それに対して東南アジ アの油やしは優良な果実が多量に揃って生産されるので, 自ら核や油の良質 
のものが得られた.

6. 住民農業のなかでの油やしは，多数の樹が集団的に栽培されないため に多量の果実の集荷には長期間を要することとなる. その結果集荷期間中に 油の品質が劣化することが多い，ことに高温湿潤のもとでの劣化はさらに著 しく促進される，なかんずく果肉中の油は著しい悪影響を受けることになる. これに対して東南アジアの油やし栽培では果実が農園に隣設された工場にい ち速く集められて適切な処理加工を施されるので, 核, 油の品質を集荷およ び処理過程において少化させることがきわめて少ない。

7. 東南アジアの油やしは適切な肥培管理下で生産されるので, 単位面積 当りあるいは個々の樹当りの収量が多く, 生産コストを低下させ得る可能性 が高い。これに対して西アフリカの油やしは零細な住民の低劣な技術下に生 産されるのでコストダウンの余地が少ない.

8. 油やしはココやしとは異なり果肉からのパーム油と核からのパーム核 油の 2 種の油が採取されるが，前者の油はことに即時搾油を必要とするので 溨培現地での製油施設が特に必要であり,この点から油やしは農園農業用作 物としての適性が高い.したがって油やし栽培の形態としては東南アジアに おける栽培形式は西アフリカのそれよりも進んでいるといえる. 因にコュや しは果笑の胚乳を乾かしていわゆるコプラを生産し，これが貿易品となるの で一般の農家でも簡単な操作で商品たるコプラを生産することができる.し たがって必ずしも農圊農業用作物としてのみ取扱う必要はなく，むしろ諸事 情から（例えば農家の現金収入源としての利用）零細な農民による少数栽培の望 ましいことが多い。

9. 今日に特いても東南アジアの産品が西アフリカのものより優れている といわ礼るのは以上のような理由から肯定できるが，東南アジアの農園に栽 培されている油やしの樹秢は既に限界にきているし，戦後肥培が不適切であ ったのでその生産が著しく落ちてきている。この事実は第 3 表に示したよう に, インドネシアの油やし栽植総面積中成木園面積の占める割合が $8 \sim 9$ 割 ああること，招よびへクタール当りパーム油収量が1940年頃の約 3 トンから 1961年には 1.6 トンと約半分に落ちている事実からも推察されるのである. したがって早急に改植を行ならとともに肥培管理の改善を図る必要がある. これに対して西アフリカにおいては従来の品質不良樹からの採取を取り止め, 
第 3 表 インドネシアにおける油やしの栽培面積, パーム油生産鲳ならびに収罯

\begin{tabular}{|c|c|c|c|}
\hline $\begin{array}{ll} & \text { 年 } \\
\text { 項 } \text { 目 }\end{array}$ & 1940 & 1958 & 1961 \\
\hline 栽 植 総 面 積(a) & 109. $6(1,000 \mathrm{ha})$ & 104.5 & 105.0 \\
\hline 成 木 園 面 程(b) & 78.1 (1, 000ha $)$ & 92.4 & 88.1 \\
\hline パーム油生産量(c) & $239,887 \quad(t)$ & 147,693 & 145,780 \\
\hline ヘクタール $\mathrm{c} / \mathrm{a}$. & $2,189 \quad(\mathrm{~kg})$ & 1,413 & 1,388 \\
\hline 油収量 & $3,042(\mathrm{~kg})$ & 1,598 & 1,655 \\
\hline
\end{tabular}

（資料） Statistic Pocketbook of Indonesia 1962，上り引用.

第 1 図 ナイジェリア，コンゴおよび マラヤの日照時間の比較

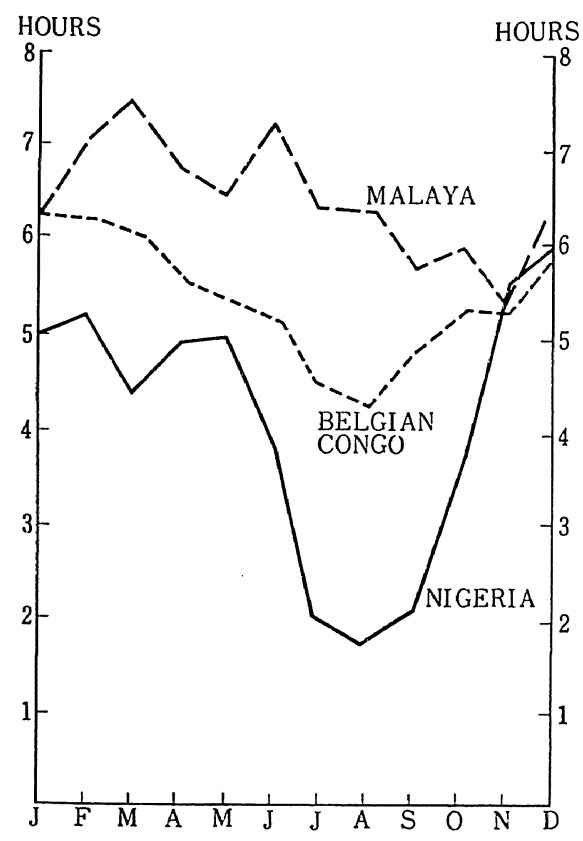

（注）ナイジェリアは Benin, ベルギー領 コンゴは Yangambi, マラヤは Ipoh における測定.
早急に優良品種を選択しこれを 近代的農園農業のような形のもと に適切な肥培管理下で育成するこ とが必要であろう。

10. 以上は主として両地域にお 汀る油やし栽培の歴史的事奏にも とづく考察から導き出した結果で あるが，次に自然条件特に日照時 間の関係から雨地域の油やし找培 に対する適性を比較検討してみる に，第1図に示すごとくナイジェ リアは日照時間がマラヤに比べる と 1 年を通じて少なく，ことに6 月から11月にかけて著しく少ない。 コンゴは両者の中間の日照時間が ある、この事実はマラけの方が物 質生産の上からは油やし栽培に好 都合ともい党る。ごく大胆な言い 方ではあるがナイジェリアは油や しの自然植生の適地ではあろらが, 農菜生産からみると必ずしも完全 に好条件を具えているとはいえないようである。しかしこのことに関しては 
さらに深く研究してみなければ確実なことはいえない。

（東京教育大学農学部）

\section{The Oil Palm in West Africa and in South-East Asia An Essay of Comparative Study} Goro NisHIKAWA

(Faculty of Agriculture, Tokyo University of Education)

The aim of this investigation is to make clear differences between the oil palm production of West Africa and that of South-East Asia. In the most case, the oil palm is cultivated in West Africa by the peasant-type cultivation, while in South-East Asia, by the plantation system. From this fact, it may be considered that the quality of oil and kernel produced in South-East Asia is better than that of West Africa. Nevertheless, the oil palm trees cultivated in South-East Asia being older than those of West Africa, they must be replaced by new ones and fertilized efficiently. 